\title{
IMPLEMENTING ABS REGIME IN NEPAL THROUGH COMMUNITY BASED BIODIVERSITY MANAGEMENT FRAMEWORK
}

\author{
Bikash Paudel, Pitambar Shrestha, Bir Bahadur Tamang and Abiskar Subedi
}

\begin{abstract}
It is very evident that there is lack of well accepted and verified mechanisms as well as institutional set up for the realization of farmers' rights, including the effective implementation of International Regime on Access to and Benefit Sharing (IRABS). Community Biodiversity Management (CBM) embed good practices, proven to be effective in in-situ conservation of biodiversity through conservation through use, they also provide a base for a range of practices which serve the basis for IRABS to be affable and affordable to local communities. CBM encompasses the good practices serving documentation, conservation, facilitating exchange, providing access to genetic resources and associated traditional knowledge. Moreover, CBM also provide institutional structure and mechanism to share the benefits accruing from commercial use of the genetic resources, directly and indirectly.
\end{abstract}

Key words: Genetic resources, associated traditional knowledge, access and benefit sharing, farmers' rights, community biodiversity management

\section{INTRODUCTION}

The extreme variations in altitude, topography, climatic conditions, socio-cultural composition and farming practices have evolved immense diversity in natural flora and fauna as well as cultivated crop species in Nepal. Comprising of less than 0.1 per cent of earth's land mass, harbouring $10 \%$ all birds ( 862 species), $4 \%$ of all mammals (181 species), $1.53 \%$ of all reptiles (143 species of reptiles and amphibians), $6 \%$ of all bryophytes (687 species of algae), $3 \%$ of all pteridophytes (1500 species of fungi and 465 species of lichen) and $2 \%$ (around 7000 species) of flowering plants, hence stands 31st in world ranking in terms of biodiversity. Besides, about 200 species of commercially important medicinal and aromatic plants, 5000 species of insects, 185 species of fishes, 400 species of agrohorticultural crops, 60 species of wild edible fruits and 300 species of orchids (NBS, 2002; Gautam, 2008).

As a party to Convention on Biological Diversity (CBD), Nepal is obliged to recognise and implement provisions of protecting rights of local and indigenous communities over genetic resources while implementing access to and benefit sharing (ABS) regime. Being a member of the World Trade Organization (WTO), Nepal is committed to provide protection on plant varieties either by patents or by an effective sui generis system or by any combination thereof. In the other hand, after ratification of the International Treaty on Plant Genetic Resources for Food and Agriculture (ITPGRFA), Nepal is committed to take appropriate measures to protect Farmers' Rights over Genetic Resources and Associated Traditional Knowledge (GR and ATK). All these international commitments, are closely associated with the Nepalese agriculture since these provisions alter the ways of providing access to genetic resources, protecting the Intellectual Property Rights (IPR) of the "novel" seed as well as other technology and respecting the traditional and cultural rights of the farmers on the GR and ATK.

Although, the provisions of ABS, IPR and Farmers' Rights are to be implemented in Nepal through national legislations, none of the commitments have been reflected in any legislation. Embracing "National Biodiversity Strategy - 2002" and preparation of draft law on "Access to Genetic Resources and Benefit Sharing - 2002" are the major steps taken by Ministry of Forest and Soil Conservation (MoFSC) to abide the commitments of CBD (MoFSC, 
2002). Ministry of Agriculture and Cooperative has also finalized "National Agro biodiversity Policy- 2007" (MoAC, 2007), prepared draft law on "Protection of Plant Varieties and Farmers' Rights - 2007" for ensuring Farmers' Rights while implementing IPR regime (MoAC, 2008).

Although, the International Regime on Access and Benefit-Sharing (IRABS) is a global legal instrument, the provisions of the Convention on Biological Diversity (CBD) and Bonn Guidelines show implementation of the regime starts from local communities. While an international instrument for regulating $A B S$ is required to generate the incentive for conservation of rapidly depleting biodiversity, the execution should effectively guarantee the recognition of the local communities and indigenous people as the true custodian of the GR and ATK, and their right to make decisions on documentation, conservation, development and sustainable use and access and benefit sharing. Environmental laws are most likely to generate local environmental and social benefits when indigenous peoples and local communities have the right of free, prior and informed consent over any activities undertaken on their lands or regarding access to their traditional knowledge, innovation and practices (TKIP)(Bavikatte and Jonas, 2009).

It is apparent that the impact of an International Regime on ABS (IRABS) on local and indigenous communities will only be possible when effective and innovative mechanisms, serving as the basis for implementing IRABS in communities and appropriate institutional development among the custodians of GT and ATK, are identified, legitimated and promoted. But, it is very evident that there is lack of well accepted and verified mechanisms as well as institutional set up for the realization of farmers' rights, including the sharing of the benefits arising from the use of GR and ATK.

There have been some of the good practices in community level, like Community Biodiversity Register (CBR), Community Seed Bank (CSB), Adding Value and Marketing of genetic resources, Participatory Plant Breeding (PPB) and Participatory Varietal Selection (PVS), Community Based Seed Production (CBSP) which have been very successful tools for conservation of the local genetic resources through use. All these good practices of previous works have been embedded in the name of Community Biodiversity Management (CBM) framework. There are enough possibilities that some of these tools and approaches could serve the basis for making IRABS to be affable and affordable to local communities.

\section{OBJECTIVE}

The overall objective of the study was to assess the mechanisms which could be the basis for implementing Farmers' Rights through fair access to and benefit sharing from the use of genetic resources and associated knowledge in Nepal. The specific objective of the study was to assess the opportunities provided by CBM framework for implementation of International Regime on Access to and Benefit Sharing (IRABS) in Nepal.

\section{METHODOLOGY}

The study was an action research initiative with broad range of the activities in community, district and national level. Major part of the initiative was to implement the possible mechanisms (which could serve the basis for implementing IRABS in different type of communities in Nepal and with different type of genetic resources) and study whether that could serve as the basis for implementing IRABS. The data were gathered during a period from 2008 to 2010 from Rupakot (Kaski), Jogimara (Dhading), Bachauli (Chitwan), Kachorwa (Bara) and Tamaphok (Sankhuwasabha). The information on processes, product and effect of implementing Community Biodiversity Register, Community Seed Bank, PPB and PVS, CBSP, CBM Fund, Biodiversity Fairs were gathered separately from both qualitative and quantitative research methods as appropriate. Different studies to assess the effectiveness 
of the mechanism to implement IRABS were also conducted, by gathering the data from randomly sampled respondents and also by using different PRA tools.

Review of the previous literatures on good practices of in-situ conservation, Community Biodiversity Management and Community Biodiversity Register (CBR) has been a very important part of the research method. The paper includes review of the previous findings on a specific good practice, which provide base for the hypothesis that the mechanism could serve the IRABS to reach the community and provides some more justification based on the data gathered.

\section{CBM FRAMEWORK}

Community-based Biodiversity Management (CBM) is a participatory approach to empower farmers, farming communities, and local institutions in managing biodiversity for social, economic and environmental benefits to the community, as well as to the general public (Subedi et al., 2006). CBM embed good practices, proven to be effective in in-situ conservation of biodiversity in a brawny framework which is effective to empower the communities to control over the local genetic resources and take benefit from them.

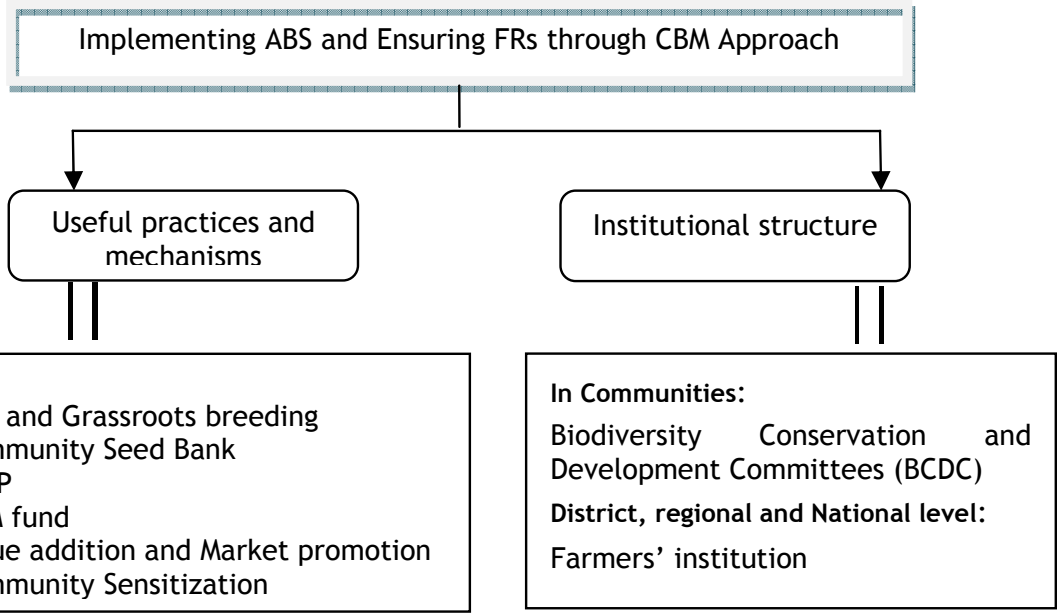

Fig. 1: CBM framework as a basis for implementing ABS Regime and ensuring FRs

Regarding documentation sharing and conservation of genetic resources and ATK, CBM framework embed participatory tools like CBR, diversity fair and Community Seed Bank. It also accommodates a range of practices like PPB, PVS and grass-root breeding for adding value to the local genetic resources through breeding process and linking the products of marvelous local genetic resources to the noble market. CBM frame accommodates the practices of strengthening local seed system and promotes farmer as producer as well as user of seed through CBSP.

To implement all the functions on management of biodiversity CBM framework also includes the structural part of activity. Biodiversity Conservation and Development Committees (BCDCs) is a model of organizing the custodians of the genetic resources which, CBM framework is promoting.

\section{CBM PRACTICES SERVING AS A BASIS FOR IMPLEMENTING ABS}

Best practices in community level, previously found to be useful in conservation of the local GR on farm (Sthapit et al., 2008), has also been verified as mechanisms to serve the basis 
for ensuring FR and implementing ABS regime. Some mechanisms have more evident functions in the process of implementing ABS; whereas some of them only contribute in the process. The tools attributing to documentation of biological diversity and ATK, empowering local communities for making decision on conservation and use, adding value to them to generate direct incentive would be essential in the process of ABS. Likely, tools supporting exchange of genetic materials and ATK and ensuring effective PIC of custodians on the process of access are also very much essential. Although, monitoring commercial use of GR and ATK and ensuring the sharing of the benefit are essentially not the function of communities, but fair and equitable distribution of the benefits that has been shared needs strong community roles. CBM encompass different tools for documenting biodiversity and ATK, empowering communities to take decisions on their management, adding value to them to generate sustainable direct benefits, share GR and ATK in a way that community will not lose their custodianship, deciding PIC in the process of providing access and sharing the benefit accruing from the commercial use. The framework of CBM also empowers communities to understand the legal and policy content in the management of genetic resources. All these best practices and their role in the process of implementing IRABS into the communities are discussed in the following chapters.

\section{DOCUMENTATION OF THE BIODIVERSITY AND ATK}

Community Biodiversity Register (CBR) is a record, kept in a register by community members, of the genetic resources in a community, including information on their custodians, passport data, agro-ecology, cultural and use values' (Sthapit et al., 2001). Under the condition that CBR is recognized in the policy and legal frameworks as the certificate of the custodians of GR and ATK, it will facilitate the process of bio-prospecting, provide the basis for the ownership (Gauchan et al., 2005) and specify communities to gain PIC while providing access. Moreover, CBR will be the base for the information to be published for effective use of defensive publication, which is believed to restrict any future IPR claim on our local GR and ATK.

Analyzing different institutional structures viz. member based $\mathrm{CBO}$, Community Forest User Groups (CFUGs), Cooperatives and Biodiversity Conservation and Development Committees (BCDCs) to maintain CBR (Subedi et al., 2005), BCDCs are found to be the most accepted institution since; it was found to be more complete, legitimate, focused and sustainable. The result showed that there should be some institution with inclusive representation of the custodian of GR and ATK in community to national level for effective implementation of ABS regime.

\section{EMPOWERING COMMUNITIES FOR MAKING DECISION ON CONSERVATION AND USE}

Researchers have verified that CBM approach is effective in empowering farming communities in applying wide ranges of practices for conservation and utilization of agricultural biodiversity (Subedi et al., 2006). These practices supporting on-farm management allow for improvement of farmers' control over and access to crop genetic resources (Bragdon and Jarvis, 2002. CBM provides the communities with the knowledge and skills on analyzing the available biodiversity and enhances their capacity to build CBM Plan. CBM uses Four Cell Analysis and some other tools for analyzing biodiversity followed by Village Level Workshops to analyze and finalize the plan.

\section{ADDING VALUE TO THE GENETIC RESOURCES AND ATK}

Addition to the value of genetic resources is needed to enable the communities conserving the important genetic resources to take direct and visible benefits sustainably. CBM framework is based on the strategy of "conservation through use". Two types of value addition are generally practiced in the communities i.e. adding value through product diversification and marketing; and adding value through breeding. They are breeding and non-breeding approach. 
Product diversification, value addition and marketing of local GR: Product diversification, value addition and linking to the market for a local GR were found to be extremely useful tools for conservation of local GR, and provide the incentive for the communities involved in conservation of the GR and ATK on farm (Sapkota et al., 2006). CBM approaches empower the communities to add value in the potential genetic resources and link them to the noble market. The benefits of the value addition and marketing of the genetic resources distributes to an individual or a group of people, according to who are involved in the process. People who have the knowledge on the practice of growing, using, protecting and marketing the particular GR will be the one who benefit from it. Thus these approaches ensure that the incurring benefits from use of GR and ATK go to the ultimate custodian.

Adding Value on GR by breeding: Participatory Plant Breeding (PPB), Participatory Varietal Selection and grass-root breeding have been successfully used for on-farm conservation of local rice varieties (Gyawali et al., 2006a; Gyawali et al., 2006b). Many researchers see PPB as an essential step to securing the world's food supply. In the process, PPB also contributes to ensure FRs in various ways (Halewood et al., 2007) and promote benefit sharing from the use of local GR.

Current Nepalese draft legislations accept farmers as breeder but, the mechanism of providing ownership on new varieties to breeder farmers is not developed. Although varieties developed by PPB (e.g. Pokhareli Jethobudo, Barkhe 3004, Sunaulo Suganda) have already been released through National Seed board (NSB), none of these varieties are under the ownership of farmers. Findings show that it is necessary to protect the varieties developed by farmers, but the contribution of other farmers providing the genetic pool should not be undermined. Even breeder farmers perceive that there should be trade off mechanism for not to restrict the farmers' rights on PPB seed when protecting the ownership right.

Financing the PPB programmes will be a mechanism of indirect (Anderson, 2006) sharing of the benefit from use of GR. Finding showed that PPB products were found to be well accessed by farmers and communities have benefited by them irrespective of group.

\section{COMMUNITY BASED SEED PRODUCTION (CBSP)}

The CBSP system provides benefits to the seed growers and share benefits with large number of the crop grower farmers. CBSP has also been a mechanism to provide incentives for the PPB farmers. The results of PPBs showed that at least 29 farmers in PPB group producing seed of Mansara, Biramphool and Jhinuwa lines in Begnash VDC and at least 13 farmers from Kachorwa village producing seed of Kachorwa lines have been found to be benefited. Seed production of the PPB varieties is not restricted to those, who have been involved in the breeding process. This show CBSP can be a mechanism of to provide incentive for the breeder farmers and also source of benefits to the other farmers who only involve them in seed production. CBSP is found to be the most successful mechanism for down-streaming the use and dissemination of PPB and/or Client Oriented Breeding (COB) products (Witcombe et al., 2009).

CBSP fills a big need for seed where farmers can get seed of the varieties they prefer. CBSP may also be a mechanism to generate benefits from seed production and marketing of promising local varieties. With present lawsuit, commercial production and marketing of non-registered landraces is illegal and processes of registration of landraces are much difficult to follow by farmers, but CBSPs are coordinating the production and exchange of the seed of local landraces among farmers in the form of Truthful Labeled (TL) seed. Whether CBSP could be an option to ensure Farmers' Rights to save exchange and sell seed for livelihood purpose; and whether it could reduce the dependency of farmers on corporate led seed supply are matter of future study. 


\section{EXCHANGING LOCAL GR AND KNOWLEDGE}

CBM framework embeds management of Community Seed Bank (CSB) as an important structural component of agro-biodiversity management. CSB has been proved to be effective in exchange of the traditional knowledge and GR in communities (Shrestha et al., 2004) and also has the potential for facilitating exchange of GR nationally and internationally. If CSB could be linked with National Gene Bank (NGB) and International Gene Banks (IGBs), it would very effectively be a model to exchange the GR in ex-situ and in-situ. Combining CSB with CBR and Prior Informed Consent (PIC) mechanism, would effectively facilitate the regulated exchange of GR and ATK.

Data collected from 120 households in Kachorwa VDC of Bara, show farmers perceive CSB have positive effect on increasing access to local seeds; development of new varieties; identification, conservation and promotion of local landraces. CSB also found to contribute in strengthening local and traditional seed system and promoting self storage of seed without affecting traditional practices of exchange of seed within and outside the villages. Many of these functions are attributing to strengthening local seed system and ultimately to ensure FR.

Table1: Frequency of farmers by their perception on effect of CSB on some attributes of seed system

\begin{tabular}{|c|c|c|c|c|c|}
\hline Aspects of seed system & Negative & No effect & Positive & $\begin{array}{c}\text { Very } \\
\text { positive }\end{array}$ & $\begin{array}{c}\text { Do not } \\
\text { know }\end{array}$ \\
\hline Access to seed of local varieties & & & $59(50)$ & $37(31)$ & $23(19.3)$ \\
\hline Access to seed of improved varieties & & $18(14.8)$ & $66(54.5)$ & $10(8.2)$ & $27(22.3)$ \\
\hline Support in new variety development & & & $66(55.9)$ & $19(16.1)$ & $33(27.9)$ \\
\hline Conservation of local landraces & & & $65(54.6)$ & $23(19.3)$ & $31(26)$ \\
\hline Identification of local landraces & & & $72(61)$ & $10(8.4)$ & $36(30.5)$ \\
\hline Protect ownership of local genetic resources & & $2(1.6)$ & $64(53.7)$ & $5(4.2)$ & $48(40.3)$ \\
\hline Local seed system & $1(0.85)$ & $11(9.4)$ & $54(46.1)$ & $2(1.7)$ & $49(41.8)$ \\
\hline Self storage of the seed in household & $14(11.6)$ & $29(24.1)$ & 45 (37.5) & $2(1.6)$ & $30(25)$ \\
\hline Exchange of seed from / to neighbors & $9(7.62)$ & $48(40.6)$ & $26(22)$ & $5(4.2)$ & $30(25.4)$ \\
\hline Exchange of seed to other villages & $11(8.66)$ & $57(44.8)$ & $23(18.1)$ & $1(0.78)$ & $35(27.5)$ \\
\hline
\end{tabular}

Figures in parenthesis indicate the percentage of the row total

It was found that about $82 \%$ of the farmers perceive that CSB may enjoy the ownership of the local landraces maintained by it and 69\% of them felt that CSB can enjoy the rights to provide PIC to the outsiders on behalf of the farming communities.

The national gene bank is under establishment in Nepal. The NGB has huge potential of reducing the cost of collection of the genetic resources from CSBs if the proper coordination between NGB and CSB established. The process of continuous development in the GR through in-situ conservation could be ensured through proper linkage of CSB with NGB. Moreover, through linkage of NGB and CSB, farmers may have easy access to the variety of options of GR to domesticate and repatriate (Majaju et al.,).

Moreover, CBM also have specific tools for locating, identifying and sharing the biological diversity and traditional knowledge i.e. biodiversity fair. CBM frame include biodiversity fair, where farmers collect and put all the biological diversity in their area, share the knowledge about particular biodiversity, exchange the seed and planning materials among them. Biodiversity fairs were found to be very much effective in exchanging the genetic resources and ATK, within community (Adhikari et al., 2004). Analysis of diversity fair on its effectiveness to disseminate different message showed that it was found to be effective in creating awareness and interest among diverse stakeholders on the importance and value of local genetic resources and making the spectator feel about the ownership. 


\section{PROVIDING ACCESS TO GENETIC RESOURCES}

Providing access to genetic resource is very important part of implementing ABS regime. Although, the access to the genetic resources will be on the basis of Material Transfer Agreement (MTA) between party seeking access and a National Authority, the role of the communities in providing access is also fundamental. The role of communities in the process is given through the right of providing PIC. The provision of providing the PIC report by Village Development Committee as mentioned ABS bill - 2003 is against the principle since PIC is the role of the holder of the GR and ATK. PIC should be granted by individual/group holding GR and ATK but not by any part of the government like VDC. A community institution, which represents all the holders of GR, would be necessary to grant the PIC. CBM framework establishes the Biodiversity Conservation and Development Committees in VDC level for coordinating management of biodiversity in community level; and granting PIC and facilitating the process of distributing benefit could easily be the part of their role.

\section{DISTRIBUTING THE BENEFITS}

Any of the mechanisms described above could be the part of benefit sharing package in indirect benefit sharing. Because, financing "Value addition projects (both breeding and non-breeding), CSB and CBSP have shown that the ultimate benefits been distributed fairly and equitably. Moreover, CBM framework encompasses mechanism to distribute benefits aroused from use of common property resources including genetic resources within community. Community Biodiversity Management Fund (CBM fund) is found to be the mechanism to fairly and equitably distribute monitory benefits raised from the commercial use of GR and ATK (Paudel et al., 2010). CBM funds are established in revolving fund mechanism, to support conservation of local genetic resources and generate benefit by using them. Findings show that CBM fund is being operated as a mechanism to provide incentive for farmers especially to the minorities and woman for being involved in conservation (UNDP/SGP, 2009).

The mechanism of mobilizing CBM fund shows that each and every household in the VDC are eligible in taking loan from the fund. Findings indicate that the fund is distributed in all wards of the VDCs and has reached in hand of up to $7 \%$ of the total households in a single year. With the experience of success in equitably distributing benefits by CBM fund in community level, there is an ample possibility that the monitory benefits acquiring from the use of community GR could directly go to this fund and shared equitably and used in biodiversity management and community welfare.

Table 2: Summary of CBM fund users in study sites in 2009

\begin{tabular}{|c|c|c|c|c|c|c|c|c|}
\hline S.N. & Site & \multicolumn{3}{|c|}{ Total fund (NRs) contribution } & \multicolumn{3}{|c|}{ No. of users of fund } & \multirow{2}{*}{ Coverage } \\
\hline & & Donor & Community & Total & Male & Female & Total & \\
\hline 1. & Kachorwa, Bara & 500000 & 30000 & 530000 & 10 & 80 & 90 & All 9 wards \\
\hline 2. & $\begin{array}{l}\text { Jogimara, } \\
\text { Dhading }\end{array}$ & 150000 & 15300 & 165300 & 29 & 21 & 50 & lards \\
\hline 3. & $\begin{array}{c}\text { Tamaphok, } \\
\text { Shankhuwasabha }\end{array}$ & 150000 & 15000 & 165000 & 25 & 23 & 48 & $\begin{array}{c}29 \text { farmer groups } \\
\text { of all } 9 \text { wards }\end{array}$ \\
\hline
\end{tabular}

\section{COMMUNICATE POLICY AND LEGAL MESSAGES TO COMMUNITY}

Farmers and local communities perceive and interpret policies differently from decisionmakers (Subedi et al., 2003). Farmers' management of the specific varieties on his/her farm is determined by farmers' understanding of many agro-ecological and socio-economic factors; including the government policies. CBM framework includes different tools and approaches to communicate policy messages to the community. Community level events like biodiversity fairs, folk song competition, rural street drama, village level workshops, 
joint monitoring visits and community level trainings are generally organized to disseminate the knowledge on biodiversity management and related policy message in communities. Specific tools like village level workshops and trainings were found to be most effective to communicate the legal message on biodiversity, but methods like biodiversity fair and folk song competition were also equally useful to aware the mass on their right and responsibilities regarding conservation and use of GR.

Table 3: Comparison of different communication methods based on judgment of 7 users taken through rating

\begin{tabular}{|l|l|l|l|l|l|l|}
\hline $\begin{array}{c}\text { Communication } \\
\text { methods }\end{array}$ & \multicolumn{1}{|c|}{$\begin{array}{c}\text { Communicate } \\
\text { policy message }\end{array}$} & $\begin{array}{c}\text { Number of } \\
\text { Audience }\end{array}$ & $\begin{array}{c}\text { Interest of } \\
\text { community }\end{array}$ & $\begin{array}{c}\text { Participation } \\
\text { of people }\end{array}$ & Effect & Cost \\
\hline $\begin{array}{l}\text { Folk song } \\
\text { competitions }\end{array}$ & $* *$ & $* * * * *$ & $* * * * *$ & $* * * * *$ & $* *$ & $* * *$ \\
\hline Diversity Fair & $* * *$ & $* * * * *$ & $* * * * *$ & $* * * * *$ & $* * * *$ & $* * * * *$ \\
\hline $\begin{array}{l}\text { Rural street } \\
\text { drama }\end{array}$ & $* * *$ & $* * *$ & $* * *$ & $* * *$ & $* * *$ \\
\hline $\begin{array}{l}\text { Village level } \\
\text { workshops }\end{array}$ & $* * * *$ & $* *$ & $* * *$ & $* * *$ & $* * *$ & $* * *$ \\
\hline Trainings & $* * * *$ & $* * * * *$ & $* *$ & $* * *$ \\
\hline
\end{tabular}

${ }^{*}$ Very low, ${ }^{* * * * *}$ very high

The effectiveness of the biodiversity fairs to communicate different concepts were analyzed by asking about 78 spectators randomly selected in the fairs about how many of the concepts they noticed and how many of them they understood. Result showed that on an average, respondent noticed about half of the concepts $(8.6 \pm 0.5)$ and understood $6 \pm 0.6$ messages out of 16 that has been asked. The study showed that biodiversity fair is very effective tool in disseminating knowledge related to concept and importance of local biodiversity, mobilize the mass in conservation of biodiversity and local resources and making people realize their right on GR and ATK.

\section{CONCLUSION AND RECOMMENDATIONS}

Community-based Biodiversity Management (CBM) is a participatory approach to empower farmers, farming communities, and local institutions in managing biodiversity for social, economic and environmental benefits to the community, as well as to the general public. It includes good practices, proven to be effective in in-situ conservation of biodiversity, it provide a base for a range of practices which may serve as the basis for IRABS to be affable and affordable to local communities. Regarding documentation and the sharing and conservation of genetic resources and ATK, CBM provide options of participatory tools and practices like the CBR, Biodiversity Fair and CSB. It also accommodates a range of practices, such as Participatory Plant Breeding, Participatory Varietal Selection, Value Addition and Market Promotion of local genetic resources and Community-Based Seed Production successful in pragmatic adoption of "Conservation through Utilization"; financing on these activities could easily be course to indirect sharing benefits, fairly and equitably. Moreover, CBM also provides a model institutional structure to ensure the right of the holders of GR and ATK on providing PIC during access to genetic resources and sharing the benefits accruing from the commercial use of those resources and knowledge. Gap in the legal base on registering such type of innovative institutional structure in Nepal, there is instant need of provision for registering the farmers' organization in Nepal.

There are very few well accepted and proven innovative mechanisms for trickling down IRABS into the local communities. Further study may be necessary to generate more evidence on the appropriateness of some of the CBM tools on implementing IRABS, but relevance of most of the tools are already proved and realized by large groups of the stakeholders. The findings of the study on the CBM framework would be very much useful for tracking down the legislation of Nepal on regulating $A B S$ regime. 


\section{REFERENCE}

Adhikari, A., Rana, R. B., Sthapit, B., Subedi, A. , Shrestha, P. K., Upadhaya, M. P. , Baral, K. P., Rijal, D. and S. Gyawali, 2004. Effectiveness of diversity fair in raising awareness of agrobiodiversityagro biodiversity management. In: Sthapit B R, Upadhaya M P, Shrestha P K and D. I. Jarvis (eds). Onfarm conservation of agricultural biodiversity in Nepal (vol. II), Managing diversity and promoting its benefits. Proceedings of the second national workshop 25-27 August 2004, Nagarkot, Nepal. pp.236-245.

Anderson, R., 20056. Results from an International Survey on Farmers' Rights. Background Study - 2, The Farmers' Rights Project. Fridtjof Nansens Institute, Norway.

Bavikatte, K. and Jonas, H., 2009. Bio-cultural Community Protocols as a Community-based Approach to Ensuring the Local Integrity of Environmental Law and Policy. Square Brackets - Issue 2, November 2009, CBD, Bonn.

Bragdon, S. and D. Jarvis, 2002. The role of legislature, policy and agrobiodiversityagro biodiversity management on-farm. In: Gauchan D., Sthapit B. R. and D. I. Jarvis (eds.). Agrobiodiversity conservation on-farm: Nepal's contribution to scientific basis for national policy recommendation.

Gauchan D., Adhikari A., Shrestha P. K. and B. Sthapit , 2006. Impact of market and value addition initiatives on crop diversity and livelihood improvement in western mid-hills of Nepal. In: Sthapit B and D. Gauchan (eds.). On farm management of agricultural biodiversity in Nepal: lesson learned. Proceedings of a national symposium, 18-19 July 2006, Kathmandu, Nepal. pp.196-206

Gauchan, D., Sthapit, B. and A. Subedi, 2005. Community biodiversity register: a review of South-Asian experience. In: Subedi A, Sthapit B, Upadhaya M and D. Gauchan (eds.), Learning from community biodiversity register in Nepal, Proceedings of National Workshop 27-28 October 2005. pp.3-13.

Gautam, J.C., 2008. Country Report on the State of the Nepal's Plant Genetic Resources for Food and Agriculture (Nepal), Submitted to Commission of Genetic Resource for Food and Agriculture, FAO. pp.38. Available at: ftp://ftp.fao.org/ag/agp/countryreports/NepalFinalReport.pdf

Gyawali, S., Sthapit, B., Bhandari, B., Shrestha, P., Joshi, B. K., Mudwori, A., Bajracharya J. and P. Shrestha, 2006a. Participatory plant breeding (PPB): a strategy of on-farm conservation and improvement of landraces. In: Sthapit B and D. Gauchan (eds). On farm management of agricultural biodiversity in Nepal: lesson learned. Proceedings of a national symposium, 18-19 July 2006, Kathmandu, Nepal. pp.164-173.

Gyawali, S., Sthapit, B., Bhandari, B., Bajracharya, J., Shrestha, P. K., Upadhaya, M. and D. Jarvis, 2006b. Jethobudo landrace enhancement for in-situ conservation of rice in Nepal. In: Sthapit B and D. Gauchan (eds). On farm management of agricultural biodiversity in Nepal: lesson learned. Proceedings of a national symposium, 18-19 July 2006, Kathmandu, Nepal. pp.146-163.

Halewood, M., Deupmann, P., Sthapit, B. R., Vernooy, R. and S. Ceccarelli, 2007. Participatory plant breeding to promote Farmers' Rights. Bioversity International, Rome, 2007. pp.2-3. Available at: http://idl-bnc.idrc.ca/dspace/handle/123456789/38593

Majaju, C., Zinhanga, F. and E. Rusike, 2003. Community seed banks for semi-arid agriculture in Zimbabwe. In: CIP-UPWARD, Conservation and sustainable use of agriculture biodiversity - a sourcebook. International Potato Center- Users' Perspective with Agricultural Research and Development, Los Banos, Laguna, Phillippines (Vol 2), strengthening local management of agricultural biodiversity, pp.294-301. Available http://www.eseap.cipotato.org/upward/Publications/Agrobiodiversity/_ pages\%20294301\%20(Paper\%2038).pdf

MoAC, 2008. Plant variety protection and farmers' right (draft). Ministry of Agriculture and Cooperatives, Nepal

MoAC, 2007. Agrobiodiversity Policy of Nepal (2007). Ministry of Agriculture and Cooperatives, Nepal.

MoFSC, 2002. Access to and benefit sharing from the use of genetic resources. Ministry of Forest and Soil Conservation, Nepal

NBS, 2002. National Biodiversity Strategies - 2002. Ministry of Forest and Soil Conservation, Nepal.

Paudel, B., Shrestha, P., Tamang, B. B. and P. K. Shrestha, 2010. Taking a community biodiversity management approach to ABS in local communities: The Nepal experience. Square Bracket. Issue 3. CBD, Bonn. pp 1011. Available at http://www.cbd.int/doc/newsletters/square-brackets/square-brackets-2010-05.pdf 
Sapkota, T., Bhandari, B., Regmi, B., Rijal, D., Subedi, A., Shrestha, P., Gauchan, D., Poudel, I., Subedi, S., Tamang, B. B. and R. Tiwari. Marketing of agro-biodiversity in Nepal: option for onfarm conservation of agro-biodiversity through market incentives. In: Sthapit B and D. Gauchan (eds). On farm management of agricultural biodiversity in Nepal: lesson learned. Proceedings of a national symposium, 18-19 July 2006, Kathmandu, Nepal. pp196-205.

Shrestha, P., Subedi, A., Rijal, D., Singh, D., Sthapit, B. R. and M. P. Upadhaya, 2004. Enhancing local seed security and on-farm conservation through community seed bank in Bara district of Nepal. In: Sthapit B. R., Upadhaya M. P., Shrestha P. K. and D. I. Jarvis (eds). On-farm conservation of agricultural biodiversity in Nepal (vol. II), Managing diversity and promoting its benefits. Proceedings of the second national workshop 25-27 August 2004, Nagarkot, Nepal. pp 70-76. http://idl-bnc.idrc.ca/dspace/handle/123456789/36097

Sthapit, B. R., Joshi, K. D., Rana, R. B., Upadhayay, M. P., Eyzaguirre, P. and D. Jarvis, 2001. Enhancing biodiversity and production through participatory plant breeding, an exchange of experience from South and South East Asia. Proceedings of the international symposium on PPB and PGR enhancement, PGRA/IDRC/DFID/DDS/IPGRI/ICARDA. Pp 29-54.

Sthapit, B., Gauchan, D., Subedi, A. and D. Jarvis,, 2008 (eds). On Farm Management of Agricultural Biodiversity in Nepal: Lesson Learned. Proceedings of a national symposium, 18-19 July 2006, Kathmandu, Nepal (Reprint). Pp. 2-211

Subedi A, Shrestha P, Shrestha P, Gautam R, Upadhyay M, Rana R, Eyzaguirre P and B. R. Sthapit, 2006. Community biodiversity management: empowering communities to manage and mobilize agricultural biodiversity. In: Sthapit BR and D Gauchan (eds.), On-farm management of agricultural biodiversity in Nepal: lesson learned, Proceedings of national symposium, 18-19 July 2006. Kathmandu, Nepal, pp.140-145.

Subedi, A., Gauchan, D., and B. Sthapit, 2003. Developing policies on agricultural biodiversity conservation and use in Nepal In: CIP-UPWARD, Conservation and sustainable use of agricultural biodiversity: a sourcebook, PP.553-558. Available at: http://www.eseap.cipotato.org/upward/ Publications/Agrobiodiversity/pages\%20553-558\%20(Paper\%2066).pdf

Subedi, A., Shrestha, P., Shrestha, P., Gautam, R., Upadhaya, M., Rana, R. B., Eyzaguirre, P. and B. Sthapit, 2006. Community biodiversity management: empowering community to manage and mobilize agricultural biodiversity. In: Sthapit B and D. Gauchan (eds.). On farm management of agricultural biodiversity in Nepal: lesson learned. Proceedings of a national symposium, 18-19 July 2006, Kathmandu, Nepal, pp.140-145.

Subedi, A., Sthapit, B., Shrestha, P., Gauchan, D. and M. Upadhaya, 2005. Emerging methodology of community biodiversity register: a systhesis. In: Subedi A, Sthapit B, Upadhaya M and D. Gauchan (eds.), Learning from community biodiversity register in Nepal, Proceedings of national workshop 27-28 October 2005. Pp 75-83

UNDP/SGP, 2009. Strengthening the capacity of community seed bank for enhancing local seed security and agrobiodiversikty conservation in central Terai. Available at: http://sgp.undp.org/web/ projects/9740/stregnthening_the_capacity_of_community_seed_bank_for_enhancing_local_seed_s ecurity_and_agrobiodiver.html

Witcombe, J. R., K. P.Devkota, Virk, D. , Rawal, K. B., Prasada, S. C., Kumar, V. A and K. D. Joshi, 2007. Client oriented breeding and seed supply. Available at http://www.future-agricultures.org/ farmerfirst/files/T3a_Witcombe.pdf 